\title{
The Influence of Parents Support to Children on The Result of Student Competency Test Achievements
}

\author{
Aditya Ramadhan*, Heni Handayani, Dian Rahdiani \\ Center for Assessment and Learning \\ Ministry of Educational and Culture \\ Jakarta, Indonesia \\ *rencanaku17@gmail.com,niek_handayani@yahoo.com, dianrahdiani84@gmail.com
}

\begin{abstract}
Parents' support in the era of advancement in science and technology is needed to prepare students with characters who have success in learning and have 21st-century competence. Parents' support for their children can be supported when learning at home, or parents' support for various activities and programs at school. How big the influence of parents' support on the achievement of student competency tests is the research purpose. This research uses descriptive statistical analysis methods and factor analysis methods as inferential analysis for questionnaire data. The data used the AKSI SMP 2019 survey data for three subjects, namely Indonesian Language, Mathematics, and Sciences, as well as 17.098 student questionnaire data. The data were obtained from the Center for Assessment and Learning, Ministry of Education and Culture. The results showed that the correlation coefficient between seven items with latent variables has a large value and a positive value. This shows that the more intensive seven forms of parents' support for their children, the greater the index of parents' support for children in the learning process. Then, the average scores of students from Indonesian Language, Mathematics, and Sciences, who received parents' support during the learning process, were relatively higher than students who had enough or less support from their parents during the learning process. Some form of parents' support is still less intensively felt by students, namely to give attention to what children are learning in school and about children's education plans going forward so that parents' support for this must be further enhanced for their children.
\end{abstract}

Keywords-AKSI, parents' support, learning achievement, factor analysis, competency test achievement

\section{INTRODUCTION}

Improving the quality of education has always been a major concern for the implementation of development in the field of education. The implementation of education in Indonesia is carried out in three forms, namely: formal, informal, and nonformal education. The success of education is measured by the results of student achievement. As expressed by Hamalik [1], "Learning achievement is the level of learning outcomes achieved by students after carrying out learning activities in an effort to achieve predetermined learning objectives".
Student learning achievement can be determined through two factors, namely factors from within the student (internal) and from outside the student (external). Purwanto [2] states that internal factors are divided into physiological factors which include physical condition and five senses; and psychological factors consisting of intelligence, motivation, talents, interests, and readiness of students. Meanwhile, external factors are divided into environmental factors and educational instrumental factors. Environmental factors consist of guidance, support, and motivation from family (parents); and educational instrumental factors including curriculum, programs, facilities, and teachers.

One of the factors supporting the success of student learning is a positive synergy between teachers and parents, such as providing support and the involvement of parents in student learning both at home and at school. According to Hawes and Jesney in Padavick [3], parental support can be interpreted as parental participation in student education and experiences. In line with this, Boonk et al. [4] state that children's achievement scores are divided into two things, namely: 1) The role of parents at home, which means what parents do to help develop children's learning; 2) The role of parents in school means every activity or behavior of parents who are tied to the school.

Guiding children to learn at home means helping to develop attitudes, values, habits, and skills that encourage student success through the willingness of parents to provide support to children so that they excel in learning [5].

Increasing student motivation to learn is an integral activity that must be included in learning activities, whether carried out by students themselves, parents, or teachers. But in reality, parents and teachers cannot always work together positively to support the success of student learning outcomes. The majority of the teachers of our public schools especially at primary level are not very serious and committed to their duties. The parents, who wish to educate their children, cannot just rely on school learning. They have to make some additional arrangements for their children to achieve success. As majority of our population is illiterate and cannot provide proper coaching at home to their children, it is a matter of great concern for them to arrange 
some additional source for their children within their limited income. Chohan and Khan [6] states that parents who take an active role in their children's learning achievements are offering the support their kids need to be successful at school. And according to the results of Liestari and Safari research [7], it is stated that the concern of parents for children by guiding children to do homework can help children get higher scores in the TIMSS study.

This is in line with the statement of Henderson and Berla [8] which says: "the most accurate predictor of a student's achievement in school is not income or social status but the extent to which that student's family is able to: Create a home environment that encourages learning Express high (but not unrealistic) expectations for their children's achievement and future careers Become involved in their children's education at school and in the community".

A phenomenon that often occurs today, parents fully surrender their children's learning activities to the school. Quality meeting time between parents and children is becoming increasingly limited because many parents work long hours (from morning to night). The quality of the meetings in a limited time sometimes becomes not optimal, because at the time of meeting, parents and children are busy with social media and their respective activities in cyberspace. Coupled with the proliferation of online learning courses, parents consider this to be sufficient to provide support for their child's learning process. Even though parents are the first and foremost educators in shaping children's character, paying attention morally, helping to improve achievement and accompanying the development of students' talents and potential.

Support from parents in the era of advances in science and technology is needed in order to prepare students with good character who have success in learning and have 21-st century competence. Support provided by parents can be done through many things, for example in terms of material, facilities and infrastructure, emotional, psychological, and prayer. Parental support will be a strong motivation and encouragement for students to learn [9].

According to this background, the problem formulated in this study is to find out how much influence parental support to children on the result of student competency test in the AKSI 2019 survey. Therefore, the purpose of this study was to identify the influence of parental involvement especially the support provided by parents to children on the results of AKSI 2019 surveys.

\section{METHODS}

The research method used is descriptive and inferential statistical analysis methods. This method is used to detect the effect of support from parents to students on academic achievement based on the results of AKSI 2019 (grade 8) survey. The data used in this study are AKSI 2019 surveys for 3 subjects, Indonesian (BIN), Mathematics (MTK), and Sains (IPA) as well as questionnaire data for students regarding the involvement of parents and teachers. This research uses question items that are in the questionnaire for the involvement of parents and teachers. This question item consists of seven statements that explore the support provided by parents to their children as shown in Table 1. This data was obtained from the Center of Assessment and Learning, Research and Development Agency and Books, Ministry of Education and Culture (Balitbangbuk, Kemendikbud).

The data used were 17,098 data from class VIII junior high school students, which were data from students who received student questionnaires about the involvement of parents and teachers. The following are questions and statement items used to measure the level of parental support for children in this study

TABLE I. FORMS OF PARENTAL SUPPORT FOR CHILDREN IN LEARNING PROCESS

During this school year, how often did the parents do the following?

\begin{tabular}{|c|c|c|c|c|c|}
\hline No & Item & Never & Sometimes & Often & Always \\
\hline a. & $\begin{array}{l}\text { Providing support when } \\
\text { children face problems at } \\
\text { school }\end{array}$ & & & & \\
\hline b. & $\begin{array}{l}\text { Encouraging them to } \\
\text { always be confident in } \\
\text { their abilities }\end{array}$ & & & & \\
\hline c. & $\begin{array}{l}\text { Reminded me of the } \\
\text { importance of studying }\end{array}$ & & & & \\
\hline d. & $\begin{array}{l}\text { Discussing problems that } \\
\text { children face with their } \\
\text { friends at school }\end{array}$ & & & & \\
\hline e. & $\begin{array}{l}\text { Parental attention to what } \\
\text { children learn at school }\end{array}$ & & & & \\
\hline f. & $\begin{array}{l}\text { Parental attention to } \\
\text { children's future education } \\
\text { plans }\end{array}$ & & & & \\
\hline g. & $\begin{array}{l}\text { Discuss career plans that } \\
\text { interest me }\end{array}$ & & & & \\
\hline
\end{tabular}

The research used the factor analysis method as an inferential analysis for questionnaire data. Factor analysis is used to look for factors that can explain the relationship between several items that are observed or in other words reduce the number of observed variables into factors that can represent data. Furthermore, the resulting factor scores were categorized into three categories, namely "good", "sufficient", and "less" based on the distribution of index values (loading factors) per quartile.

\section{RESULTS AND DISCUSSION}

AKSI is a diagnostic assessment to measure student abilities and student weaknesses and their causative factors which we can see from the various questionnaire instruments filled in by each respondent. The factors that affect academic achievement are complex, including intrapersonal, interpersonal, organizational, community, and environmental variables. For this reason, it is important to know the factors 
that are likely to influence on the students' academic achievement.

Data obtained from the seven items in the questionnaire about the support provided by parents to their children were analyzed using R, SPSS, and Microsoft Excel software. Figure 1 shows the frequency of parental support for children throughout the 2018/2019 school year.

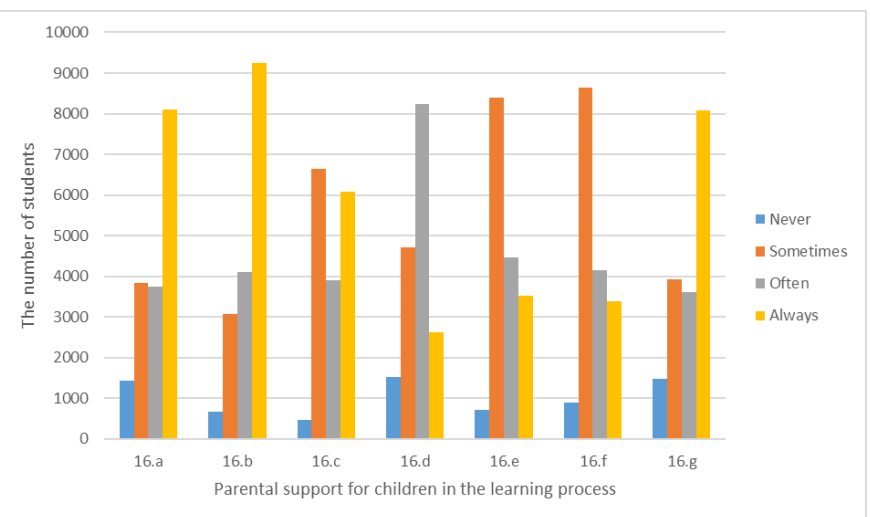

Fig. 1. The intensity of parental support from the student's perspective.

Figure 1 shows that there are four contexts of parental support for the child's learning process, which have high intensity in the student's perspective or other words, the four contexts of parental support are often or even always carried out by parents to their children in the child's learning process. The four forms of support are: (a) providing support when children face problems at school, (b) encouraging them to always be confident in their abilities, (d) discussing problems that children face with their friends at school, and (g) discuss career plans that interest me. Meanwhile, two contexts of parental support for children in the form of (e) parental attention to what children learn at school and (f) parental attention to children's future education plans have low intensity in the student's perspective or in other words, the students who think that this is still not a concern of their parents or only occasionally done by parents to their children. Thus, the intensity of support and attention from parents to children based on students' perspectives in this study is mostly done on things that are more psychological in nature, for example on problems at school, problems with friends, self-confidence, and future work. Meanwhile, the intensity of parental support for what is learned at school and about their future education plans is still considered by students to be lacking.

The effect of parental support for children on the results of AKSI 2019 surveys at the junior high school level, a factor analysis of the seven statement items was carried out, which was then used as a factor for the latent variable, namely parental support for children in supporting the learning process.

Table 2 shows the correlation coefficients between the seven statement items with their latent variables. The correlation coefficient between the seven statement items with the latent variable shows a large value and is positive. This shows that the more intensive each form of parental support for children, the greater the index of parental support for children in the learning process. The largest correlation coefficient is found in the statement item (b) encouraging children to always be confident, which is 0.828 , and the statement item (f) regarding parents' concern for their child's education plan, which is 0.8 .

Table 3 shows the results of the factor analysis of the construct variables which are reduced to two factors. These two factors illustrate the support that parents provide to children in the learning process with a cumulative variance of $69.65 \%$. This means that these two factors can explain the variance of the latent variable constructs of $69.65 \%$.

TABLE II. CORRELATION BETWEEN AND LATENS VARIABLES

\begin{tabular}{|c|l|c|}
\hline \multicolumn{3}{|c|}{ Parental support for children in the learning process } \\
\hline a. & Providing support when children face problems at school & 0.787 \\
\hline b. & Encouraging them to always be confident in their abilities & 0.828 \\
\hline c. & Reminded me of the importance of studying & 0.740 \\
\hline d. & $\begin{array}{l}\text { Discussing problems that children face with their friends at } \\
\text { school }\end{array}$ & 0.787 \\
\hline e. & Parental attention to what children learn at school & 0.777 \\
\hline f. & Parental attention to children's future education plans & 0.800 \\
\hline g. & Discuss career plans that interest me & 0.768 \\
\hline
\end{tabular}

TABLE III. FACTOR ANALYSIS RESULTS (2 FORMED FACTORS)

\begin{tabular}{|l|l|l|l|}
\hline Component & Total & \multicolumn{1}{|c|}{ \% of Variance } & Cumulative (\%) \\
\hline 1 & 3.053 & 43.616 & 43.616 \\
\hline 2 & 1.822 & 26.032 & 69.648 \\
\hline 3 & 0.673 & 9.619 & 79.268 \\
\hline 4 & 0.533 & 7.621 & 86.888 \\
\hline 5 & 0.359 & 5.126 & 92.014 \\
\hline 6 & 0.305 & 4.358 & 96.372 \\
\hline 7 & 0.254 & 3.628 & 100.000 \\
\hline
\end{tabular}

Based on the results of the factor analysis, the resulting factor component is used to score a parent's support for the child in the learning process. The scores are categorized into "less", "sufficient", and "good" based on the statistical value of the quartile data distribution (q1, q2, q3).

Figure 2 shows that the average score of BIN, MTK, and IPA for students who received parental support during the learning process was relatively higher than for students who received sufficient or less support from their parents during the learning process. For example, the average BIN score for students who received support from parents in the "good" category was 50.70 , the "sufficient" category was 48.72 , and the "less" category was 41.71. Although the increase is slight in each category, the support provided by parents to children is sufficient to illustrate that the role of parents in the learning process has a positive influence on the development of children's learning achievement and achievement at school.

From the result presented, we conclude parents' support is important in improving children's achievement. This result corroborates Ronel Mondragon, that parents' involvement in activities that are effectively planned and well-implemented 
results in substantial benefits to children, parents, educators, and the school [10].

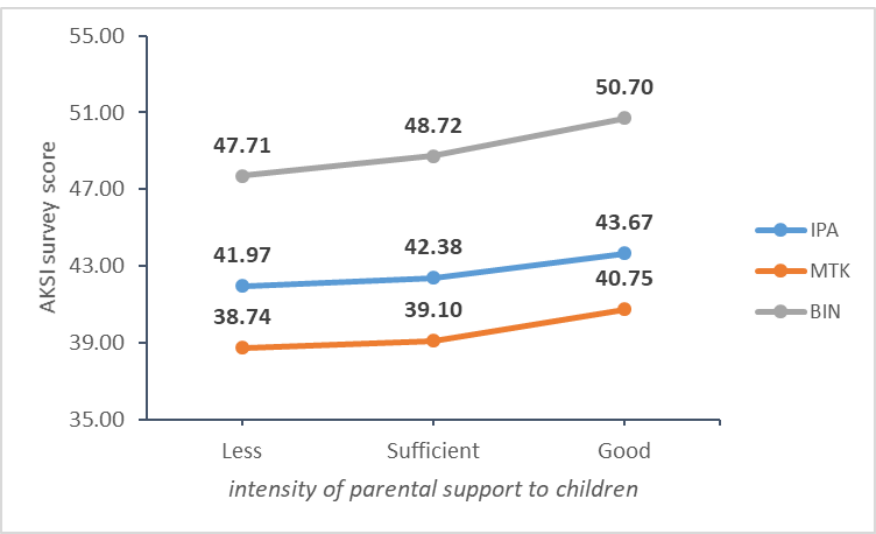

Fig. 2. The relationship between the intensity of support provided by parents to children on the results of AKSI 2019.

Other studies in this area showed that there were differences in academic achievement scores between the parent involvement profiles, where high and medium-involved parents had children with higher academic achievement than low involved parents [11]. Some studies concluded that parental involvement enhances the academic achievements of their children [12]. Similar results from Astuti et al. [13] state that the increasing role of parents in guiding, encouraging children will have an impact on improving children's achievement in school.

\section{CONCLUSION}

Parental support for children is needed for children as a form of motivation to learn in achieving achievement. This form of support varies and has been widely used, although there are several forms of parental support that children do not feel intensively, namely parents' attention to what they learn at school and children's education plans in the future. This does not mean that parents never ask how and what students learn at school, but it can mean that parents still pay little attention to direct solutions to difficulties or direct guidance to their (SMP) children when children learn school lessons at home. This is similar to paying attention to a children's education in the future. Talking and discussing how to plan and what to do so that children can enter the high school they hope for, can be a form of parental support for their children's education plans in the future.

\section{ACKNOWLEDGMENT}

The authors are grateful to Center of Assessment and Learning Balitbangbuk, Kemendikbud RI for releasing the AKSI 2019 data for which the data were used for this study. Besides, the authors would like to thank friends at the Center for Assessment and Learning Balitbangbuk, Kemendikbud RI who have provided input and suggestions, so that this paper is realized.

\section{REFERENCES}

[1] O. Hamalik, Metode Mengajar dan Kesulitan-Kesulitan. Bandung: PT Rosdya Karya, 1990.

[2] N. Purwanto, Psikologi Pendidikan. Bandung: Remaja Rosdakarya 1991

[3] J.F. Padavick, "Parental involvement with learning and increased student achievement," Unpublished doctoral's dissertation, Walden University, Minneapolis, Minnesota, USA, 2009.

[4] L. Boonk, H.J.M. Gijselaers, H. Ritzen, and S. Brand-Gruwel, "A Review of The Relationship between Parental Involvement Indicators and Academic Achievement," Educational Research Review, vol. 24, pp. 10-30, 2017.

[5] S. Stainback and W. Stainback, How to help your child succeed in school. New York: Simon \& Schuster, 1988

[6] B.I. Chohan and R.M. Khan, "Impact of Parental Support on the Academic Performance and Self Concept of the Students," Journal of Research and Reflections in Education June, vol. 4, no.1, pp. 14-26, 2010 .

[7] S.P. Liestari and Safari, "Dampak Pendampingan dalam Mengerjakan PR dan Kebiasaan Orang Tua Membaca Terhadap Capaian Akademik Anak dalam TIMSS 2015," Indonesian Journal of Education Assessment (IJEA), vol. 2, pp. 50-55, 2019.

[8] A. Henderson and N. Berla, A New Generation of Evidence: The Family is Critical to Student Achievement. Columbia. MD: National Committee for Citizens in Education, 1994.

[9] A. Bakar, I.M. Kamaruddin, and M.T. Yang, "Hubungan antara Minat Pelajar dan Sikap Ibu Bapak dengan Prestasi Matematik Terbaik Pelajar," Journal of Educational Psychology and Counseling, vol. 1, pp. 25-43, 2006.

[10] G.M. Sapungan and R.M. Sapungan, "Parental Involvement in Child's Education: Importance, Barriers and Benefits" Asian Journal of Management Sciences \& Education, vol. 3, no. 2, pp. 42-48, 2014.

[11] L. Lara and M. Saracostti, "Effect of Parental Involvement on Children's Academic Achievement in Chile," Journal Frontiers in Psychology, vol. 10, Article 1464, 2019.

[12] S.Y. Kaukab, "The Impact of Parent/Family Involvement on Student's Learning Outcomes," International Journal of Research-Granthaalayah, vol. 4, pp. 72-81, 2016.

[13] D. Astuti, W.D. Rivaie, and Y. Ibrahim, "Analisis Peran Orang Tua dalam Meningkatkan Hasil Belajar Siswa Kelas X SMK Muhammadiyah Pontianak", [Online]. Retrieved from https://media.neliti.com/media/publications/21294-analisis-peran-orangtua-dalam-meningkat.pdf. 